\section{Janusz Pasterski}

University of Rzeszów

\section{Parallel Worlds: On Bilingualism and Cultural Polyphony in the Poetry of Andrzej Busza*}

Keywords: Andrzej Busza, bilingualism, biculturalism, 20 $0^{\text {th }}$-century and contemporary poetry.

Literary bilingualism is often the result of permanent rootedness in two cultures. Individual biographical experiences result in many opportunities here, the most frequent of which are, for example, emigration and settling in a new country or living on an ethnic and linguistic borderland. In each case, however, it is a particularly complex situation and related not only to the category of the language of artistic expression, but also to the notion of cultural (and often national) identity. The duration of intercultural contact and its beginning in relation to one's individual age is of great importance. The earlier and the longer, the more durable it is and more it penetrates the consciousness. In border areas, such contact is somehow natural, perpetuated both by everyday customs and the rituals of the symbolic sphere. In the case of expatriation, however, we are dealing with a fundamental cultural change understood as the main factor influencing the shaping of the immigrant's consciousness and the arranging of their internal intercultural relations.

If an individual encounters dissimilarity or alienation, it may lead to various interactions, including various forms of cultural adaptation, from the

* Polish original: (2016) Światy równoległe. O dwujęzyczności i polifonii kulturowej w twórczości Andrzeja Buszy. Wielogłos 2(28), pp. 63-79. 
simple acquisition of the ability to function only within one's own diaspora, to assimilation, i.e. full integration into the culture of the host country. The intermediate form in this process is biculturalism, that is the position of an individual in relation to two different groups, which results in a hybrid form of cultural identity. It is the effect of existing in two social environments, between which a relationship of a non-equivalent, dynamic structure is established. This is usually distinguished by the gradual reduction of distance from the new environment while at the same time reducing or modifying the ties with the native culture. Bilingualism, present even in subsequent generations, is a link that integrates both such environments. Biculturality is, therefore, above all, characteristic of first-generation immigrants as a formula for mitigating cultural change and enabling the reduction of axionormative conflicts. It produces a separate, compilatory type of personality, located outside unequivocally defined communities and systems.

In the works of the Polish writers of the post-September pro-independence emigration, the phenomenon of biculturalism was not a desirable factor. The ideological identification of Polish circles, especially in Great Britain, strongly emphasised the patriotic attitude and the preservation of national cohesion. The close connection of the pro-independence mission with care for the condition and development of Polish culture was postulated, for example, by the "flagman of the emigration" Tymon Terlecki [see: Terlecki]. In this situation, acculturation or assimilation tendencies had to be perceived as divergent from Polish interests. Nevertheless, some eminent artists in exile treated it in a more universal way, not as a failure, but as an opportunity to enrich their own writing. Such an attitude was characteristic of, among others, Czesław Miłosz, Witold Gombrowicz, Jerzy Pietrkiewicz, Gustaw Herling-Grudziński and Sławomir Mrożek. The latter wrote in a letter to Wojciech Skalmowski: "I am convinced that we owe the quality of my, our, writing in Polish, our way of thinking, expressing ourselves, writing, to emigration. This is the positive side of our otherwise unhappy fate" [Mrożek and Skalmowski 2007, p. 547].

However, while in relation to these writers a stronger insight into the culture of the country in which they settled took place at a mature age and was not connected (apart from Jerzy Pietrkiewicz) with a change in the language of artistic expression, in the case of the youngest generation of this emigration the situation turned out to be much more complex. Young artists who gathered around the London magazine "Kontynenty", including Andrzej Busza, Bogdan Czaykowski, Adam Czerniawski, Zygmunt Ławrynowicz, Bolesław Taborski and Florian Śmieja, were in a position determined also by a British education, having attended local schools and universities, a good knowledge of English and their being practically bilingual. The fact that they had settled down in English culture, their knowledge of realities and traditions, as well as their understanding of the local world of values allowed them to acquire bicultural competences rapidly. At the same time, however, aware of their or- 
igin and attached to the Polish language, they developed their creative work in their native language, although in strong opposition to the passéist models and stereotypes of emigration poetry. What distinguished them was their conscious reflection on the language material, their attitude of rebellion motivated by a sense of "triple alienation" and their use of Polish and English literary traditions.

Within the circle of poets forming the London "Kontynenty" group special attention should be paid to the poetic work of Andrzej Busza as the most complicated case of biculturalism and literary bilingualism. In order to understand his cultural and linguistic background, it is necessary to recall the basic biographical facts ${ }^{1}$. Andrzej Busza was born on 17 November 1938 in Cracow. His father was a doctor and his mother was a daughter of Apolinary Tarnawski, a well-known doctor, pioneer of natural medicine and the founder of a sanatorium in Kosiv, Pokuttya. It was from there that the whole family was forced to flee on 17 September of the following year after the invasion of the Red Army [see: Tarnawski, pp. 7-8; Tarnowska 2011, p. 233]. Then, travelling through Romania and Cyprus, Andrzej Busza found himself in Palestine in June 1941 together with his mother, brother, grandparents and uncle Wit Tarnawski. Thus Palestine became for him the land of his childhood, where he lived from the age of three to nine, i.e. 1941-1947. There he began his pre-school education (in a Polish and for a short period English kindergarten in Jerusalem), and then his school education, finishing the first year of the Polish primary school also in Jerusalem. Polish was his first language, but he grew up in a multicultural environment, in contact with different traditions and languages. In an interview with Beata Tarnowska, he recalled this diversity in the following manner:

I grew up in a bubble of Polishness, in the Polish language. [...] But the landscape and reality of Palestine are still close to me today [...]. Various traditions, cultures and languages were coming together here at that time. When I went shopping with Mum, for example to an Arab shop, French was the language of communication; in Jewish shops one would often use German. Moreover, we rented rooms in a house also inhabited by Armenians. My Polish school was located in the so-called Greek colony. At home, Mum was helped by an Arab woman who had a son slightly older than me, so I learnt a little Arabic [Tarnowska 2011, pp. 234-235].

For obvious reasons, however, it was not an idyllic childhood. The time of the war and the increasing tensions in Jewish-British and Jewish-Palestinian

1 Maria Danilewicz-Zielińska described poets from the "Kontynenty" group as "mysterious youngsters", and their biographies as "colourful, almost novel-like" [Danilewicz-Zielińska, p. 317]. 
relations left many traces of horror in his memory ${ }^{2}$. They will return in the poet's works.

Andrzej Busza spent the next eighteen years of his life in England, where he attended the English boarding school in St. Joseph's College in London, followed by English studies at the prestigious University College London (1963). He also taught English for two years in a London middle school. Throughout this time, he functioned in two parallel cultural spaces: in an English environment during the school or academic year, and in a Polish environment during summer and holiday breaks. This duality required him to switch codes and eventually created a kind of spiritual and linguistic balance, according to which English became for him the language of science and professional matters, while Polish was the language of intimate and family life. Years later, the poet called this state "cultural schizophrenia":

For years I have lived and cultivated a schizophrenic mode of existence, speaking one language at home, and another in the street, the classroom, or the draughty departmental corridor. In the daytime I analysed sonnets by Shakespeare and Hopkins; at night I wrote poems in the language of Herbert, Różewicz, and Białoszewski [Busza 1987, p. 62].

At the same time, during his studies, he established contact with the Polish academic youth community and at the end of the 1950s he joined a group of young artists already operating in London, gathered around the magazine "Kontynenty - Nowy Merkuriusz" (later called "Kontynenty"). He belonged to the editorial team and participated in the literary life of the Polish immigrant community. From the very beginning, he made it very clear that his views were different, strong and clearly defined. He became famous for his speeches in editorial discussions, during which he was determined to defend his right to write in Polish, and at the same time clearly explained the distinctiveness of the generational experiences of the youngest émigré poets, demanding understanding and acceptance of their choices ("My environment, especially the youngest members of it, who grew up abroad, knows Poland only from second hand accounts, from parents' stories, from reading. For us, Poland is an abstraction" [Busza 1960, p. 10]).

The third period of Andrzej Busza's life is connected with Canada. In 1965, the poet, his wife and daughter left for British Columbia, where, thanks to Bogdan Czaykowski's efforts, he received a full-time lecturer post in English literature at the University of British Columbia in Vancouver. Busza, who was rooted in English culture but who wrote in Polish, decided to take a step in his life that brought him improved living conditions and professional stability, but

2 Andrzej Busza, for example, was an eyewitness to the bombing of the extremist Jewish organisation Irgun Tsvei Leumi in the "King David" hotel in Jerusalem on 22 July 1946 [see: Tarnowska 2004, pp. 225-228]. 
at the same time pushed him away from both cultural sources. His distance from the Polish language and the activity of the London emigration environment was much deeper than his distance from the "Britishness" that he still had contact with as he professionally dealt with English literature. Initially, however, Andrzej Busza strongly supported his ties with Poland and the Polish language. In 1967 he came to Poland for the first time, in 1969 he published his first collection of poetry entitled Znaki wodne [literally: Watermarks] at the Institute of Literature in Paris, and two years later he published a bilingual volume entitled Astrolog w metrze. Astrologer in the Underground. In the 1970s, he continued to write in Polish (e.g. the Kohelet poem from 1975), but he already felt a certain discomfort in using his mother tongue. Many years of poetic silence followed, which the author himself described later in one of his conversations as the result of an internal transformation that took place within him under the influence of "deep (both enriching and painful) personal experiences" and "wider socio-cultural phenomena" [Niewiadomski and Busza, p. 134]. Their essence, as one can guess, was the loss of contact both with Polish reality and language.

I have been teaching English literature for many years, I have got to know it more and more deeply, I was becoming familiar with the language, its poetic potential, secrets, tricks, sound texture - said the poet, receiving the Turzański Foundation Award for 2005-and at some point I realised that my knowledge of Polish is poorer than that of English [Busza 2008b, p. 317, transl. by K. S.].

As a consequence of this transformation, he wrote poems in English, that is using a tool that did not restrict his creativity and allowed him to express himself in full ${ }^{3}$.

Busza published his next collection of poems Glosy $i$ refrakcje only in 2001, and two years later another bilingual volume Obrazy z zycia Laquedema. Scenes from the Life of Laquedem. The works included in these two small books were written in English and translated into Polish by Bogdan Czaykowski. Despite the change in the language medium, the poet consistently directed his works at Polish readers, confirming his presence within the circle of Polish literature. This resulted in a very complex and unique communication situation, in which English became the real means of contact between the poet and the Polish reader. Bogdan Czaykowski, an outstanding poet, researcher and Busza's closest friend since the years spent in London, played an important role in this process. He correctly recognised the essence of the thoughts and approaches of the author of Kohelet, finding the right equivalents for them

3 In an interview with Beata Tarnowska, Andrzej Busza expressed his doubts as to the rightness of the decision made at that time: "It cannot be ruled out that the choice of the English language was to a certain extent influenced by the awareness that I am not so efficient when it comes to the use of Polish syntax... But to this day I still do not know if it was not a mistake" [Tarnowska 2011, pp. 242-243]. 
in the Polish language. After Czaykowski's death in 2007, Busza published a joint bilingual volume (in each other's translations) Petnia i przesilenie. Full Moon and Summer Solstice (2008) and his Polish 1997 poem Kohelet (2008). In recent years, rejecting the idea of self-translating his own poems, Andrzej Busza has entrusted their translation to Beata Tarnowska, Roman Sabo, Justyna Fruzińska and Jacek Gutorow. The translations by the first two translators made up his most recent collection Niepewność (literally: Uncertainty; 2013), while the translations by Fruzińska and Gutorow appeared in the quarterly "Fraza" [Busza 2015, pp. 42-50]. What is even more complicated, in the volume Niepewność, of the eight poems, seven were translated from English, and one was originally written in Polish Zabawa w metafizyke (literally: The Game of Metaphysics). This proves that the poet is still trying to write in Polish, and his more frequent visits to Poland and contact with the living Polish language in recent years have also resulted in attempts to break the constraints he feels.

According to this briefly outlined biography, the poetic activity of Andrzej Busza is clearly divided into two different language stages with a long break of twenty-six years in the middle. It would, therefore, be a rare example of linguistic transformation within the poetic work of an already fully moulded author with an important, but not very extensive literary output in his mother tongue.

This case can be treated as a model and as an atypical one at the same time. It is a model case because it relates to the poet's biography and the visible imbalance in the structure of his personal relations between the country and language of origin and the country and language of settlement. In a sense, the cultural and linguistic competences of the surrounding world in a "natural" way have the lead over consciously developed ones, although only by the power of internal need, skills and opportunities to function in the initial culture, i.e. spatially very distant and unreal in the sense that it was never an experience of constant and real influence (it is difficult to describe as such the errant of his childhood in Palestine, participation in the life of the Polish immigrant youth community in London or later short tourist trips to Poland). These have always been experiences either mediated by others (parents, family, migrant communities) and developed in the diaspora, or short-term, superficial and perforce stereotyped by the stay of the Canadian Pole in his homeland. His atypicality, on the other hand, comes from his attachment to Polish literature and the rejection of the possibility of joining the circle of English literature of Canada. In other words, the change in the language of literary activity and the probably stronger embedding in the local reality did not translate into a potential opportunity to gain new readers. The linguistic and cultural capital of English was used as a communication medium because the author's intention is to publish works in Polish and direct them to Polish readers, that is "existence through translations". This does not preclude, of course, the possibility of treating this output (mainly from a formal point of view) as part of Canadian literature in 
English, but it would also have to involve publishing the original versions of works in collections or magazines issued there ${ }^{4}$. However, the poet prefers to publish his collections in Polish or, which seems optimal, in bilingual form, but in Polish publishing houses.

The encounter with such a rare cultural phenomenon and a peculiar literary experiment leads to many questions concerning the problematic scope of this work and identity issues, its developmental dynamics and conditions of linguistic communication, as well as the literary tradition and stylistic or genre choices. It is therefore worth mentioning at the outset that we are dealing here with achievements that are structurally bipartite, but at the same time internally coherent and consistently developed. Neither linguistic nor geographical criteria, nor the thematic component are, in the case of Busza's poetry, the most important discriminants and factors determining its place within the "household" of Polish or Canadian literature. This function cannot be assigned to the poet's individual identity because it has an exceptionally complex and dynamic structure. In an interview with Jurgen Hesse, Busza clearly emphasised this internal multilayeredness:

[...] being bilingual entails not only the question of the language which we use, but also our attitudes. I would even suggest our emotions. Our emotions are probably a little bit different when one is operating in one linguistic context and then another one. When I am speaking to Poles, and then when I am speaking to Englishmen and Canadians, I am a slightly different person, I think.

[...] my life is also complicated because I am Polish, I am British, and I am a sort of Canadian. There is this certain hierarchy of emotional authenticity. I think I can say that at the emotional level I am most Polish. Then comes 'Englishness;' in many ways I am more English than Canadian [Hesse, pp. 38, 39-40].

Busza's work is extremely peculiar because it is not modified by the changes in language, and the subject matter is consistently developed without any relation to the current place of residence. He does not manifest unequivocal and specific cultural ties or belonging to a specific literary tradition; on the contrary, he eagerly emphasises universality and the lack of unequivocal rooting. "Actually, I do not belong anywhere", he declares, "or more precisely, as I express it in the poem Babilon, I belong "everywhere and nowhere" [Tarnowska 2011, p. 248]. In his opinion, the meaning of the poem is determined by the act of personal reading, and the cultural contexts of the work by the senses bestowed by the interpretation.

4 The poetic work of Andrzej Busza was noticed in Canada after the publication of the bilingual volume Astrolog w metrze. Astrologer in the Underground (1971), which received several press reviews, and also after the publication of the Volvox anthology, a collection of poems "in the unofficial languages" of Canada, which included poems by Busza and Czaykowski translated into English. The biography and discussion of the poet's output have also been published in Encyklopedia of Literature in Canada [see: New, pp. 167-168]. 
As early as the first, Polish period of his poetic activity, Andrzej Busza's poetry was distinguished by its linguistic originality, efficiency of imagination and domestication in the tradition of universal codes of culture: the Bible, mythology, philosophy, literature, painting or music. From the very beginning, the author of Znaki wodne developed a general outline of a poetic model, which led him towards a strongly expressed individualism and interest in epistemology, ethics, tradition and diverse cultural topics. Its core was unlimited creative freedom and the abandonment of the emigrant perspective of the literature of "duties" in favour of a modern understanding of the problems of existential alienation and rootedness. Like a contemporary wanderer, sometimes Baudelaire's flâneur, he was looking not for a distant homeland, but for the truth about the world and himself. However, the knowledge acquired was not edifying, and scepticism and pessimism appeared for good in the poems of the poet. Time, which usually clashed with the fragility and beauty of existence, became the most important partner in the lyrical dialogue. As Justyna Budzik puts it, "the subject in Busza's poetry looks at his existence not through the prism of the place, but through the prism of the times in which he lives" [Budzik, p. 300].

Therefore, the author of Znaki wodne was occupied with human existence, the melancholic consciousness of passing in the world of inaccessible cognition and striving for intellectual mastery of this universe, rather than with emigrant alienation, nostalgia or ideological and generational disputes. The lack of existential rootedness took over the whole burden of the poetic perception of the world. The dark, pessimistic vision of the world dominated the whole collection revealing a sense of absurd existence. Swans, for example, have become its pictorial metaphor, which in the poem under this very title are figures of death and a manifestation of the power of passing away:

płyną łabędzie

czarne

do cieni przybite

czarnych

żagle słoty

oprawne w słońce

(swans swim

black

flattened to the shadows

black

dirty weather sails

framed in the sun)

[Busza 1969, p. 15, transl. by K. S.] ${ }^{5}$

5 Unless otherwise stated, all translations of poetry are more or less literal and provided solely for the purpose of this paper. 
It was not a real and concrete reality, but a symbolic and mythical one, which hid terror and emptiness under the surface of things and phenomena. "He grows into the darkness" [ibidem], the poet says, and announces the coming nothingness. It is also one of many figures of melancholy present in this poetry, in this case evoking a poem by Charles Baudelaire Le Cygne (The Swan).

The poetics of this poem and many others from the volume Znaki wodne, especially the primacy of the poetic image, characteristic restraint, the use of colour schemes and symbols - all this indicates a reference to the poetry of the English imagists from the beginning of the $20^{\text {th }}$ century, who prefer a similar frugality and discipline of language, and above all, the precision and purity of the poetic image [see: Wącior, p. 18; Hutnikiewicz, pp. 120-126]. Thomas Ernest Hulme's theoretical thought, which rejected romantic agitation as the basis of art in favour of classical objectivity with the idea of clarity and precision, was also close to the author of Łabędzie. The avant-garde idea of returning to the poetic image and combining an intellectual and emotional layer in it remained an inspiring model of writing, all the more so as it referred primarily to working assumptions, leaving aside programmatic or ideological involvement. It was also often associated with symbolic tendencies or the expressionist contrast of opposites.

Even in his early Polish poems, Andrzej Busza eagerly used the tradition of English literature, referring to the works of Eliot, Hopkins, Yeats or the achievements of imagism mentioned above. French symbolism and Spanish modernism were also close to his heart. At the same time, like most of the artists from the London "Kontynenty" group, he attentively observed national poetry after 1956, the development of linguism, "turpism" (the aesthetics of ugliness) and the rebirth of classicist tendencies, and was fascinated by the poems of Herbert and Białoszewski.

An interesting combination of these two main traditions was achieved in the last work from the "Polish language period", printed in the December 1975 issue of "Kultura", i.e. in the extensive poem Kohelet, which in its essential sense complemented the subject matter present in the debut volume, while in an artistic sense was a multidimensional reference to the English and Polish forms of poems and the "wisdom" entries in Ecclesiastes. As Beata Tarnowska points out in her afterword to the next edition of the poem, the poet took the name and role of the person who "convenes, tells, teaches" from the Hebrew title of this book, as well as the concept of vanitas, which forms the main thread of the work. On the other hand, he derived an original genre formula from the extensive tradition of the "poetic Parnassus mountains". In Polish

6 In 1977-1982, Andrzej Busza still made attempts to write in Polish, trying to broaden his own poetic skills with new syntactic and compositional solutions, as well as a slightly different range of problems. During this period several works were created, which were only published in 2005 and 2006 in "Fraza". At that time, however, he already used English [see Busza 2005, pp. 9-10; Busza 2006, pp. 195-206]. 
literature, it has an important point of reference in Czesław Miłosz's A Treatise on Poetry, devoted to the twentieth-century history of poetry, its individualities and phenomena, styles and conventions, as well as the relations between nature, history, man and God. In the English literary and cultural tradition such a form of personal, social or environmental panorama has been known since the Middle Ages, thanks to such works as e.g. The Canterbury Tales by Geoffrey Chaucer, Essay on Criticism by Alexander Pope or In Memory of Major Robert Gregory by William Butler Yeats [see: Busza 2008a, p. 23]. Andrzej Busza's Kohelet is a polyphonic poem in which the author combines two narrative orders, led simultaneously by the "self" personified in the form of the Old Testament sage and the contemporary "self", which is a porte parole of the author. However, the two voices merge in a common tonality of vanitas, in a sense above time and history. The first voice is the structural frame of the whole and a kind of universal perspective, while the second voice evokes in lyrical close-ups portraits of contemporary Polish writers and poets captured in moments of alienation and full of despair at the encounter with the illusion of literature. There is, for example, an image of Czesław Miłosz:

widziałem Miłosza jak w pustej auli

czesał włosy białymi palcami

widziałem starego katastrofistę

pochylonego jak chimera

nad Zatoką San Francisco

nadsłuchiwał o zmroku głosów z Litwy

a widział tylko za ciemną wodą

tandetne niebo Swedenborga

ale nazajutrz rano gdy góra Tamalpais

znów brała na bary miedziane zorze

prostował się w oknie na świat otwartym

i z hartowaną pogodą dziękował

za białe żagle za błękitne morze

(I saw Miłosz as if in an empty hall

he combed his hair with white fingers

I saw an old catastrophist

bent like a chimera

by San Francisco Bay

he listened to voices from Lithuania at dusk

and he saw only behind dark water

the cheap sky of Swedenborg

but the next morning when the mountain Tamalpais

once again took the copper dawns on its shoulders

he straightened himself in the window open to the world

and thanked with hardened weather

for the white sails for the blue sea)

[Busza 2008a, pp. 7-8, transl. by K. S.] 
In a sense, authors called as witnesses of emptiness and nothingness penetrating from all sides confirm Kohelet's diagnosis, because both literature and human life are marked by the same streak of vanitas that brings to light the hidden dimension of suffering, loneliness and despair. "Nie będzie bowiem pamięci / tak mądrego jak i głupiego / a potomne czasy / wszystko zarówno pokryją / zapomnieniem" (For there will be no memory / as wise as it is foolish / and posterity will cover everything / forget it all), the biblical sage proclaims in the work [Busza 2008a, p. 19].

As has already been mentioned, after the publication of Kohelet there was a very long break before subsequent works were printed, combined with the most radical change that a writer can make, that is, the change of language. Subsequent volumes were written in English and translated by Bogdan Czaykowski, because Busza himself rejected self-translation. The first collection to be published in 2001 was Glosy i refrakcje, the title of which almost programmatically reflected the character of the poems included in it. Therefore, "glosses" should be understood as notes, additional explanations or comments on the problems already known from earlier works, but in a broader sense "glosses" also mean the cultural provenance of most of these poems, somehow "added" on the margins of other works and included in intertextual dialogues. "Refractions", in turn, may be combined with a nascent awareness of the disparateness between a work written in English and a translated text that eventually reaches the Polish reader, as there always remains a margin of otherness, which will not be eliminated even by the best linguistic equivalent [see Busza 1983, pp. 21-29]. In this way, Busza clearly marked the difference between the current creative situation and the evolutionary character of the collection, combining the two stages of his creative activity.

The "continuation" part of this volume includes poems, the construction and pronunciation of which refer to works from Znaki wodne. Despite the change of language, it is easy to find in them the already known thematic motifs and features of poetics, such as the focus on the poetic image and dense symbolism (e.g. Czekanie, Szkic burzy or Cedr). At the same time, the imagism was expanded by the expressiveness and density of cultural contexts. The poems' structure often began to resemble works of art, pictorial visualisations, whose aesthetic refinement was combined with a restrained, mature, elegiac distance. We should here recall Pory roku, a small poem, whose title and compositional outline refer to the musical work by Antonio Vivaldi, while the imaging and emotional aura refer to John Keats' To Autumn. But music is not the most important thing here; it is the art of painting and its history. With the help of works of art by the old masters and the quality features of their paintings, Busza presented a contemplative description of the beauty of the world. Referring to the alternate nature of the forms of vegetative rhythm, the four parts of this cycle reflect the colours and shapes of changing nature. The first part of the poem reads: 
Od kiedy przechodziłem tędy ostatni raz

Jarzębina ubrała się w barocco jagód

A przez polanki ścielą się dywany

Według ostatniej jesiennej mody

Rdzawymi brązami ciemnym złotem w rosach

Liście dębów i klonów przeplotły się geometrycznie

Na wzór brokat Owena Jonesa

Iglaste krzewy oczywiście mają jak zwykle jak zawsze

Ową szczególną barwę niebieskości Morrisa

I choć nie jesteś Galerią Tate ani V i A czy Ermitażem

Jesteś mi ścieżko moją osobistą galerią

Otwarcie nowej wystawy każdego sezonu

Codzienny wernisaż dla wiewiórek i ptaków [Busza 2001, p. 30]

(Since the last time I was passing through this place

The rowanberry has dressed in the barocco of blueberries

And carpets have spread through the glades

According to the fashion of last autumn

With rusty browns with dark gold in the dew

Oak and maple leaves interwoven geometrically

Like Owen Jones' brocades

Coniferous shrubs of course have as usual as always

This particular blue colour of Morris

And although you are not the Tate Gallery or the V and A or the Hermitage

You, path, are my personal gallery

The opening of a new exhibition each season

A daily vernissage for squirrels and birds)

[transl. by K. S.]

The poet records the colourful and multifaceted world with the inventiveness of a sophisticated aesthete, combining the boldness of imagination with a deep cultural setting. In this work, the metaphor of the path as a "personal gallery" triggers an aesthetic prism not of a mimetic or sensual vision of reality, but rather a pictorial one. In this sense, nature becomes a representation of art, and the seasons a transposition of colours and forms known from works by outstanding artists. However, the captivating beauty of nature is permeated with the thought of death. Behind the colourfulness of the Arcadian landscape, there is the terror of passing away. "Et in Arcadia Ego", repeats the author after the famous inscription from the paintings of Giovanni Francesco Guercino, as well as Nicolas Poussin. Poems from the volume Glosy i refrakcje reflect Andrzej Busza's permanent penetration into the space of universal culture (poem Hagia Sophia), as well as into the English literary tradition (e.g. the poem Wariacje). For him, the texts of culture are a kind of a repository, from which he draws topoi, motifs, notions and details. With their help he builds an erudite, intertextual and intersemiotic message. In it, the poet finds his own 
language, which serves him not so much to bear witness to reality, but to build his own story about the world.

The issue of existential non-rootedness formed the basis of Andrzej Busza's next collection, published in a bilingual version entitled Obrazy z $\dot{z} y$ cia Laquedema. Scenes from the Life of Laquedem in 2003. The title character of the Eternal Wandering Jew was used by the author to construct a parabolic story about exile and wandering as a universal archetype of human fate. This theme joined six parts of the cycle, which are half symbolic and half real reference to the poet's biography. Historical time and mythical time were combined into a whole, and the free composition of "images from life" gave them the character of allegorical generalisation. The cycle includes, among other things, images of escape from the biblical city of Gomorrah, the departures from Cracow and Kosiv in 1939, the stay in Jerusalem, the Great Fire of London of 1666, the defeat of Carthage and, finally, a symbolic vision of life in modern Babylon. One once had to flee or leave all these places because to be a human being means to be condemned to defeat and exile. There always appears someone who "exiles us once again / into steppes and deserts" [Busza 2003, p. 11]. In the ironic ending, even technological perfection does not free a man from the sense of alienation and eradication, because "we are / everywhere and nowhere" [Busza 2003, p. 13].

The Scenes from the Life of Laquedem were not so much another version of topos of Ahaswer, but rather his reinterpretation in a postmodern context, a reflection on the need for rootedness and community. The author's ironic distance does not make the contemporary wanderer look for a specific place, because each of them is available today. The real purpose of the journey is to become anchored in the space of culture, although paradoxically it is culture that most strongly reveals its illusory and fragile nature.

After publishing The Scenes from the Life of Laquedem, Andrzej Busza published a handful of new poems in Bogdan Czaykowski's translations, which were published in the "Fraza" quarterly in 2005 and 2006, and partly in the bilingual collection Petnia i przesilenie. Full Moon and Summer Solstice (2008). The last of Andrzej Busza's collections published so far, Niepewność, was issued in 2013. The late Bogdan Czaykowski was replaced by new translators. Of the eight poems included in this volume, two were translated by Beata Tarnowska, five by Roman Sabo, and one (as I have already mentioned) was originally written in Polish. This small collection reveals the author's interest in the physical side of reality, the problem of the limits of existence on the macro- and micro-scale of the universe, and consequently, a metaphysical reflection and questions about death and the possibility of the transcendent empowerment of life.

The core of Andrzej Busza's philosophical reflection is the agnostic "I do not know". It comes to the fore many times, especially in those works that deal with the subject of death. The title Uncertainty refers, for example, to 
Erwin Schrödinger's famous thought experiment, in which a hypothetical cat is both alive and dead from the point of view of quantum mechanics. And although this is at odds with common sense, such an unspecified state of affairs is real until the moment of verification. In this way, uncertainty activates its metaphysical sense. Consequently, as the poet writes, all judgments on the properties of phenomena must be "suspended".

Busza's stance is close to agnosticism, both in terms of knowing the reality and the existence of God. This last problem was undertaken by the poet in the poem Zabawa $w$ metafizyke, in which he playfully entrusted the resolution of a fundamental question to a childish game of tearing off the leaves from a daisy to the rhythm of a rhyme: there is - there is not. Such a game, of course, does not provide any answer, but at the same time it becomes a metaphor for the limitations of human cognition, which, due to the lack of real capabilities, creates substitute imaginary visualisations. Armed with tools and objective laws, science provides no more evidence than a child's rhyme. So you might just as well limit yourself to playing a game, although it leaves in your hands a naked "stem / and a naked flower" [Busza 2013a, p. 8]. This short poem, exceptionally vivid and sophisticated in sound, was written by Busza in Polish, which only confirms his still excellent knowledge of the language and his sensitivity to all its details.

While the Zabawa $w$ metafizyke refers to Polish children's play, the poem Sielanka, which features the image of the desert landscape of the future, and as a result the thought of the futility of the earthly world, interacts with Percy Shelley's sonnet Ozymandias, where a statue of a king, stepping in the sand, is an ironic sign of man's vain ambitions. Assessed from the perspective of the whole, Busza's collection Niepewność is a reflection of the crisis of modernist ideas about the world, the place of man and the existence of a transcendent source of the legitimacy of existence. The poet responds to the erosion of the traditional world order, the clash of contradictory reasons, the sterilisation of religious imagination and the experience of universal relativism with a sense of uncertainty. His agnostic "I do not know" is a confrontation of rationalistic awareness and the remnants of religious imagination with the contemporary vision of a world without a permanent structure. Although it leads to the suspension of cognitive judgments, at the same time he does not stop searching for signs other than the physical empowerment of reality.

The poetic output of Andrzej Busza is an example of bilingual writing with a clearly marked (even if extended in time) caesura. The change of language was not an ideological, cultural or identity choice. Rather, it involved a pragmatic assessment of one's own linguistic proficiency and rationalisation of the creative process. This is evidenced both by the author's own statements and by the homogeneity of his poetry. The language caesura did not turn out to be absolute, because he is still writing poems in Polish. In the system of literary communication, the caesura did not introduce any fundamental change either. 
The poems are still addressed to a Polish audience, although now through translations. And although this "code-switching", that is "switching from one language to another and vice versa, is similar to travelling between two different worlds" [Wierzbicka, p. 103; transl. by K. S.], in the case of the author of Znaki wodne these are fully parallel worlds. Bilingualism is accompanied by a cultural polyphony, which is the aftermath of multicultural personal experiences (Palestine, England, Poland, Canada). In this respect, Busza draws primarily from the Mediterranean culture mediated by Polish and English cultural heritage. He is mostly familiar with the tradition of English literature, but he also knows the masterpieces of Polish literature in depth, especially those of $20^{\text {th }}$-century poets close to him in terms of generation or art (e.g. Zbigniew Herbert, Miron Białoszewski, Czesław Miłosz, Jacek Bierezin). Into Polish literature, he "transplants" the achievements of imagism, Eliot's objectivity, poetic forms or typically British distance and irony, while in English it introduces a sense of history, moral traits, as well as sensitivity to the musical qualities of the poem. What distinguishes the poet most strongly, however, is his own perception of the world, independent of the language of expression. This is constituted by his critical attitude to the present day and the civilisational crises connected with it. It is precisely this scepticism that directs the poet towards the European cultural tradition, which has become for him a space of spiritual rootedness. He reads his individual experiences with the help of cultural paradigms, and in the tradition of culture finds a useful way of describing human existence. Busza's settlement in culture as a field of symbolic forms and the articulation of experience and images, however, finds its counterpoint in other features of the poet's aesthetic consciousness - melancholy and irony. In the first one, understood as the experience of an undefined loss, one should see a reaction to the domination of history in human life, instability, constant changes in status, a crisis of identity and values. The second one is the aesthetic category that softens the artist's pessimism, disarms melancholy, and in a more general sense, is a world-view response to the shape of contemporary reality. Thus equipped the poetry of Andrzej Busza can be perceived as a reflection of the multicultural experiences of the $20^{\text {th }}$ and $21^{\text {st }}$ century man and a literary phenomenon of contemporary cultural universalism.

\section{Literature}

Budzik, J. (2013). Zadomowieni i wyobcowani: O sytuacji pisarzy polskich w Kanadzie. Kraków: Wydawnictwo UJ; Toronto: Polski Fundusz Wydawniczy.

Busza, A. (1960). Różnice między pokoleniami w literaturze na emigracji. Kontynenty Nowy Merkuriusz 18-19.

Busza, A. (1969). Znaki wodne: Poezje. Paryż: Instytut Literacki. 
Busza, A. (1970). Astrologer in the underground = Astrolog w metrze: wiersze. Transl. from the Polish by J. Boraks, M. Bullock. Athens, Oh.: OUP.

Busza, A. (1983). O refrakcji znaczeniowej w przekładzie poetyckim. Pamiętnik Literacki (London) VII.

Busza, A. (1987). Cultural Dislocation and Poetry. Canadian Literature suppl. 1: J. M. Bumsted, A/Part: Papers form the 1984 Ottawa Conference on Language, Culture and Literary Identity in Canada = La langue, la culture et l'identité littéraire au Canada.

Busza, A. (2001). Glosy i refrakcje. Transl. by B. Czaykowski. Berlin: Mordellus Press; Toronto: Polski Fundusz Wydawniczy.

Busza, A. (2003). Obrazy z życia Laquedema = Scenes from the Life of Laquedem. Transl. by B. Czaykowski. Berlin: Mordellus Press; Toronto: Polski Fundusz Wydawniczy.

Busza, A. (2005). Powrót. Fraza 3 (49).

Busza, A. (2006). Alicja po latach. Gwiazdy. Psy. Węzły. Pojedynek. Secesyjna kąpiel. Fraza 3 (53).

Busza, A. (2008a). Kohelet. B. Tarnowska, ed. Toronto: Polski Fundusz Wydawniczy; Rzeszów: Fraza.

Busza, A. (2008b). Mowa torontońska. Fraza 3-4 (61-62).

Busza, A. (2013a). Niepewność. Transl. by B. Tarnowska, R. Sabo. Toronto: Polski Fundusz Wydawniczy.

Busza, A. (2013b). Jadąc na zachód z lotniska JFK. Psy z Manhattanu. Epifania. Transl. by J. Fruzińska. Fraza 4 (82).

Busza, A. (2015). Das Narrenschiff. Niebo. Indianin na nabrzeżu. Tajni agenci. Dla Wili. Elegia. Stephen Hawking przypuszcza. Star Trek. Transl. by J. Gutorow. Fraza 4 (90).

Danilewicz-Zielińska, M. (1992). Szkice o literaturze emigracyjnej. Wrocław: Zakład Narodowy im. Ossolińskich.

Hesse, J., ed. (1990). Voices of Change: Immigrant writers speak out. Vancouver: Pulp Press.

Hutnikiewicz, A. (1988). Od czystej formy do literatury faktu. Główne teorie i programy literackie XX stulecia. $5^{\text {th }}$ ed. Warszawa: Wiedza Powszechna.

Mrożek, S., Skalmowski, W. (2007). Listy 1970-2003. Foreword by A. Borowski. Kraków: Wydawnictwo Literackie.

New, W. H., ed. (2002). Encyclopedia of Literature in Canada. Toronto-London: University of Toronto.

Niewiadomski, A., Busza, A. (1993). Wyznania płaza. In: A. Niewiadomski, LondynToronto - Vancouver. Rozmowy z pisarzami emigracyjnymi. Lublin: Kresy.

Tarnawski, W. (1966). Mój ojciec, London: Polska Fundacja Kulturalna.

Yeats, M., ed. (1971). Volvox. Poetry from the Unofficial Languages of Canada in English Translation. Port Clements, B.C.: Sono Nin Press. 
Tarnowska, B. (2004). Między światami. Problematyka bilingwizmu w literaturze. Dwujęzyczna twórczość poetów grupy „Kontynenty”. Olsztyn: Wydawnictwo UWM.

Tarnowska, B. (2008). Posłowie. In: A. Busza. Kohelet. B. Tarnowska, ed. Toronto: Polski Fundusz Wydawniczy w Kanadzie; Rzeszów: Fraza.

Tarnowska, B. (2011). Wokót „Kontynentów”. Szkice i rozmowy z poetami. Olsztyn: Wydawnictwo UWM.

Terlecki, T. (2003). Emigracja naszego czasu. N. Taylor-Terlecka, J. Święch, eds. Lublin: Wydawnictwo UMCS.

Wącior, S. (2002). Imagizm. Źródła, inspiracje, twórcy. In: S. Wącior, ed. Poezja imagistyczna angielskiego modernizmu. Lublin: Wydawnictwo UMCS.

Wierzbicka, A. (1990). Podwójne życie człowieka dwujęzycznego. In: W. Miodunka, Język polski w świecie: Zbiór studiów. Warszawa-Kraków: PWN. 